\title{
Changes in the bacterioplankton community of oligotrophic Lake Stechlin (northeastern Germany) after humic matter addition
}

\author{
Kristine Michelle L. Hutalle-Schmelzer ${ }^{1,2}$, Hans-Peter Grossart ${ }^{1, *}$ \\ ${ }^{1}$ Department of Limnology of Stratified Lakes, Leibniz Institute of Freshwater Ecology and Inland Fisheries, \\ Alte Fischerhütte 2, 16775 Stechlin, Germany \\ ${ }^{2}$ Department of Biological Sciences, College of Science, University of Santo Tomas, España St., 1008 Manila, Philippines
}

\begin{abstract}
In an effort to better understand the dynamics of members of the bacterioplankton community in relation to humic matter (HM) addition, and to provide insight into the ecology of common and persistent as well as transient freshwater bacteria, we designed a study with a batch and a dilution approach. We used single vs. repeated HM additions in incubations with bacterial communities from the epilimnion $(0-10 \mathrm{~m})$ and hypolimnion $(40 \mathrm{~m})$ of oligotrophic Lake Stechlin (northeastern Germany). Molecular methods were applied for detailed phylogenetic characterization of bacterial community composition (BCC) every 2 wk over $8 \mathrm{wk}$ of incubation at in situ temperature. Whereas no significant differences in the development of BCC in batch vs. dilution cultures were observed, the BCC of epilimnic and hypolimnic samples greatly differed. This indicates that HM addition led to the establishment of a highly specific but different $\mathrm{BCC}$ depending on the source community in combination with the respective in situ temperature. Further, DGGE banding patterns revealed a high variability in the BCC of epilimnic and hypolimnic samples. Betaproteobacteria were consistently present and specific Alphaproteobacteria, such as members of the Roseisalinus group, Bacteroidetes, and Deltaproteobacteria were enriched only after HM addition. Other phylogenetic groups, including Actinobacteria and Gammaproteobacteria, were only sporadically present. Our approach resulted in the cultivation of a variety of bacteria such as Lysobacter, Methylobacterium, Pseudomonas, Rhodopila, and Variovorax species. The addition of HM selected for specific HM-degrading bacterial phylotypes, which are found at different depths even in the clear waters of Lake Stechlin.
\end{abstract}

KEY WORDS: Humic matter · Bacterioplankton community · Lake Stechlin · DGGE · CARD-FISH

\section{INTRODUCTION}

In freshwater systems, highly diverse bacterial populations allow for rapid and efficient adaptation to changes in substrate availability (Crump et al. 2003). Such associated changes in substrate availability indicate the ecological role of major phylotypes in the bacterioplankton community (Lindström 2000), as well as their resistance to changes in environmental conditions (Pearce et al. 2005). Our current understanding of the relationship between growth of individual bacterial populations and availability of particular sub- strates or nutrients is still rudimentary (Pernthaler \& Amann 2005). To aid in the analysis of effects of nutrient loading on the most abundant and metabolically active bacterial groups, combinations of molecular techniques and improved isolation approaches have recently been used (Hahn 2003, Hahn et al. 2003). For example, DNA fingerprint methods such as DGGE, coupled with sequencing of individual 16S rRNA gene fragments (bands), have often been used with catalyzed reporter deposition-fluorescence in situ hybridization (CARD-FISH) to rapidly determine the dominant bacterial members including those linked to 
substrate availability in aquatic environments (Crump et al. 2003, Castle \& Kirchman 2004, Gich et al. 2005, Pearce et al. 2005, Grossart et al. 2008). Furthermore, to link the structure and function of freshwater bacterioplankton, molecular techniques are combined with improved isolation techniques to isolate dominant and significant microorganisms (Hahn et al. 2004).

In most freshwater systems, the concentration and quality of the organic matter source, i.e. humic matter (HM), vary greatly in time and space (Sachse et al. 2001), and recent studies have shown that Actinobacteria and Betaproteobacteria are generally the major groups of common freshwater bacterial phylotypes (Zwart et al. 2002) that respond differently to a sudden pulse of humic matter (Burkert et al. 2003). In addition, drastic shifts in bacterioplankton community composition (BCC) may occur after such sudden pulses (Crump et al. 2003).

Interestingly, certain phylotypes have unique persistence patterns (Haukka et al. 2005), and dominant bacteria that have a better ability to utilize allochthonous substances are being found, such as Betaproteobacteria (Burkert et al. 2003). Although changes in BCC can be dramatic even between years (Newton et al. 2006), the extent of this variation and the dynamics of different members of the community are still unclear.

Thus, we designed a study using a batch and a dilution approach to provide insight into the ecology of common and persistent as well as transient freshwater bacteria of oligotrophic Lake Stechlin (northeastern Germany) after single vs. repeated HM additions. Further, we used different bacterial source communities (epilimnion: 0-10 m; hypolimnion: $40 \mathrm{~m}$ ), and incubated bacteria at their respective in situ temperatures. Individual members of the community were phylogenetically characterized to reveal detailed changes in BCC. Following HM addition, there were marked changes in BCC depending on the bacterial source community in combination with the respective in situ temperature.

\section{MATERIALS AND METHODS}

Study site. Lake Stechlin is one of the clearest lakes in northern Germany and is classified as a dimictic oligotrophic lake (Casper 1985) with low anthropogenic impact. Since this lake has been continuously studied for almost $50 \mathrm{yr}$, it has considerable ecological significance and serves as a reference lake e.g. for the European Water Framework Directive (http:// ec.europa.eu/environment/water/water-framework/ index_en.html).

The lake is situated in a forest mainly composed of beech and pine trees and lies at the northern border of
Brandenburg, close to the Mecklenburg Lake District $\left(53^{\circ} 10^{\prime} \mathrm{N}, 13^{\circ} 02^{\prime} \mathrm{E}\right)$. It was formed by the melting of dead ice after the glaciations ca. $12000 \mathrm{yr}$ ago. The lake has a maximum depth of $69.5 \mathrm{~m}$ and an area of $4.3 \mathrm{~km}^{2}$, with hypolimnetic oxygen saturation levels of up to $60 \%$.

Experimental design. The present study is based on 2 experimental approaches (batch and dilution cultures), each using 2 bacterial community sources (epilimnion: 0-10 m; hypolimnion: $40 \mathrm{~m}$ ) incubated at in situ temperatures. HM extracted from nearby humic Lake Grosse Fuchskuhle (FUKU) was added to duplicate water samples (1 l) from oligotrophic Lake Stechlin (Fig. 1). For batch cultures, only a single addition of $\mathrm{HM}$ into the water at the beginning of the experiment was performed. For dilution cultures, the bacterioplankton was introduced into fresh HM via repeated dilution every 2 wk over 8 wk of incubation. DGGE analyses of BCC were performed at 2 wk intervals. Bacterial isolates were obtained and sequences acquired from isolates and DGGE bands were phylogenetically characterized.

Sample collection. Water samples from Lake Stechlin were taken in early spring (March 2005) from 0-10 (epilimnion, pooled) and $40 \mathrm{~m}$ (hypolimnion) depths and filtered through $0.8 \mu \mathrm{m}$ Nucleopore filters (Sartorius) to remove large organisms such as algae and bacterivores.

Preliminary testing of the effects of incubation and HM addition. A preliminary experiment was conducted to test whether the applied incubation conditions (batch culture) would lead to a pronounced shift in BCC compared to the initial lake water sample after 18 d. Additionally, we tested whether HM addition alone had the potential to substantially change BCC after $18 \mathrm{~d}$ of incubation. The exact incubation conditions are given below. As indicated in Fig. A1 in the appendix, our incubation conditions did not substantially affect BCC. On the other hand, a pronounced shift in BCC occurred $18 \mathrm{~d}$ after HM addition as compared to the initial sample ( $T_{0}$ without and with HM) and the $18 \mathrm{~d}$ sample without HM. This indicates that addition of HM did not change the initial BCC and that our experimental approach is suitable for studying the effects on BCC following HM addition.

Establishment and maintenance of batch and dilution cultures. We added sterile-filtered natural HM (RO-isolate from FUKU; $50 \mathrm{mg} \mathrm{l}^{-1}$ final conc.), sterile trace mineral salts, and nutrients to 11 lake water samples in 21 sterile bottles. The RO-isolate of HM was derived from the epilimnic water of FUKU via reverse osmosis as prepared by Sachse et al. (2001). The trace mineral salts and nutrients were: $75.0 \mathrm{mg} \mathrm{MgSO}_{4}$. $7 \mathrm{H}_{2} \mathrm{O}, 43.0 \mathrm{mg} \mathrm{Ca}\left(\mathrm{NO}_{3}\right)_{2} \cdot 4 \mathrm{H}_{2} \mathrm{O}, 16.0 \mathrm{mg} \mathrm{NaHCO}$, $5.0 \mathrm{mg} \mathrm{KCl}, 3.7 \mathrm{mg} \mathrm{K} \mathrm{HPO}_{4} \cdot 3 \mathrm{H}_{2} \mathrm{O}, 4.4 \mathrm{mg} \mathrm{Na}{ }_{2}$ EDTA, 


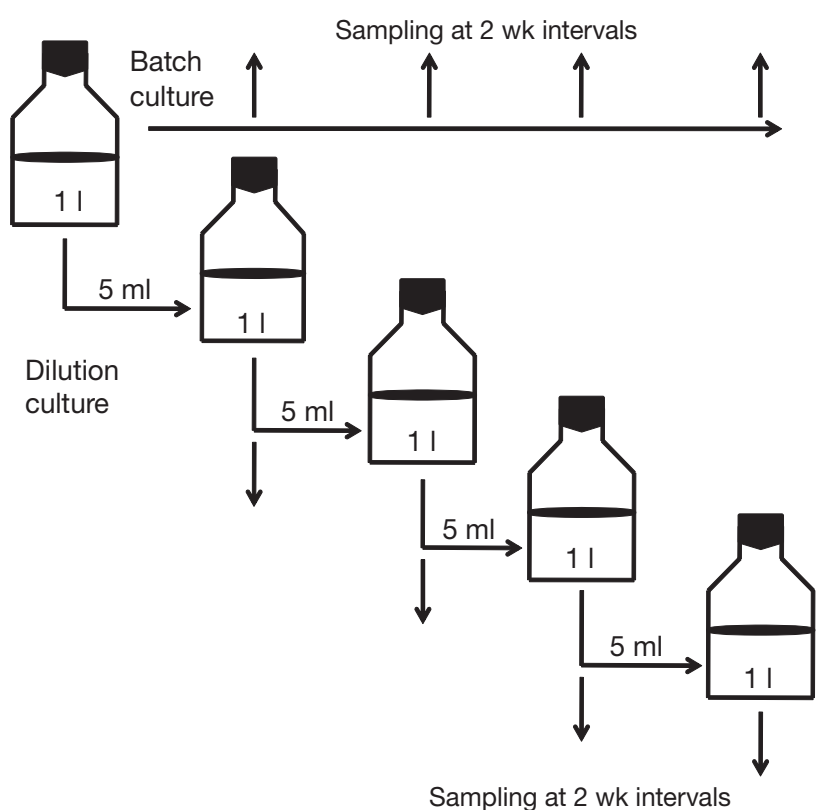

Fig. 1. Flow diagram of batch and dilution cultures at 2 wk sampling intervals. This approach was used for water samples from $0-10 \mathrm{~m}$ and $40 \mathrm{~m}$

$3.2 \mathrm{mg} \mathrm{FeCl}_{3} \cdot 6 \mathrm{H}_{2} \mathrm{O}, 1.0 \mathrm{mg} \mathrm{H}_{3} \mathrm{BO}_{3}, 0.2 \mathrm{mg} \mathrm{MnCl}_{2}$. $4 \mathrm{H}_{2} \mathrm{O}, 0.02 \mathrm{mg} \mathrm{ZnSO} \cdot 7 \mathrm{H}_{2} \mathrm{O}, 0.01 \mathrm{mg} \mathrm{CuSO}_{4} \cdot 6 \mathrm{H}_{2} \mathrm{O}$, $0.01 \mathrm{mg} \mathrm{CoCl}_{2} \cdot 6 \mathrm{H}_{2} \mathrm{O}, 0.006 \mathrm{mg} \mathrm{Na}_{2} \mathrm{MoO}_{4} \cdot 2 \mathrm{H}_{2} \mathrm{O}$, $5.0 \mathrm{mg}$ nutrient broth (Merck), $5.0 \mathrm{mg}$ tryptic soy broth (Difco), $5.0 \mathrm{mg}$ peptone (Difco), and $5.0 \mathrm{mg}$ yeast extract (Difco). Our protocol is a slight revision of the inorganic basal medium (IBM) used by Hahn et al. (2003) for growth and isolation of ultramicrobacteria of Actinobacteria.

Batch cultures were not manipulated during incubation (Fig. 1). For dilution cultures, a $5 \mathrm{ml}$ aliquot was taken at $2 \mathrm{wk}$ intervals and diluted into $1 \mathrm{l}$ of fresh lake water prepared as mentioned above. All cultures were incubated on a rotary shaker at $100 \mathrm{rpm}$ in the dark at in situ temperatures $\left(15^{\circ} \mathrm{C}\right.$ in the epilimnion; $4^{\circ} \mathrm{C}$ in the hypolimnion) for $8 \mathrm{wk}$. Samples were taken from all cultures every 2 wk (Fig. 1).

Isolation of bacteria. To acquire bacterial isolates, we plated a $1 \mathrm{ml}$ water sample from the batch and the dilution cultures onto agar plates at the end of the experiment. The plates were prepared from epilimnic or hypolimnic water supplemented with sterile-filtered natural HM, sterile trace mineral salts and nutrients (see above), and agar (1.5\%, Difco). Pure cultures were derived after subsequent isolation and recultivation. The phylogenetic affiliation of all bacteria was determined using PCR, DGGE and sequencing analyses (see below).

Total cell counts and CARD-FISH. Total bacterial abundance was determined every 2 wk using epifluo- rescence microscopy after staining with DAPI $(0.2 \mathrm{mg}$ $100 \mathrm{ml}^{-1}$ ). Numbers of Actinobacteria, Alphaproteobacteria, Betaproteobacteria, and Eubacteria were determined using an improved protocol for CARDFISH (Sekar et al. 2003). Briefly, $10 \mathrm{ml}$ from each culture were collected on Nucleopore filters $(0.2 \mu \mathrm{m}$, Sartorius) and fixed with $50 \%(\mathrm{v} / \mathrm{v})$ ethanol in $1 \%(\mathrm{v} / \mathrm{v})$ saline phosphate buffer. All filters were stored at $-20^{\circ} \mathrm{C}$ until further processing. For quantification of Actinobacteria, Alphaproteobacteria, and Betaproteobacteria, probes HGC69a (Roller et al. 1994), ALF968 (Glöckner et al. 1999), and BET42a (Manz et al. 1992) were used. Eubacterial abundance was determined with the probe mix EUB 338 I-III, which detects most Eubacteria, even including Planctomycetes and Verrucomicrobia (Daims et al. 1999). Stained bacteria were counted with a Leica DR-MB epifluoresence microscope at $1000 \times$ magnification, and at least 10 randomly selected fields of view (each with $10000 \mu^{2}$ ) were examined from each culture. Mean and standard deviations were calculated.

DNA extraction and PCR amplification of 16S rRNA gene fragments. To characterize particle-associated (PA) and free-living (FL) bacteria of the natural water samples before the beginning of the experiment $\left(T_{0}\right)$, $100 \mathrm{ml}$ of natural lake water samples were filtered through $5.0 \mu \mathrm{m}$ and then through $0.2 \mu \mathrm{m}$ Nucleopore membranes (Sartorius). To characterize temporal changes in the BCC of each culture, $100 \mathrm{ml}$ of sample were taken and filtered through $0.2 \mu \mathrm{m}$ Nucleopore filter (Sartorius) at $2 \mathrm{wk}$ intervals.

Extraction of genomic DNA was performed using a protocol with lysozyme, proteinase $\mathrm{K}$ and zirconium beads. Filters were cut into sections and placed in $2 \mathrm{ml}$ Eppendorf reaction tubes. Zirconium beads (500 mg), sodium dodecyl sulfate $(25 \%)$, and $\mathrm{Na}$ phosphate buffer (120 mM; pH 8) were added to the filter sections, which were then vortexed for $10 \mathrm{~min}$ at maximum speed to mechanically disrupt the bacteria. The bacteria were further treated with lysozyme $\left(10 \mathrm{mg} \mathrm{ml}^{-1}\right)$ and proteinase $\mathrm{K}\left(10 \mathrm{mg} \mathrm{ml}^{-1}\right)$ overnight. After addition of $\mathrm{NH}_{4}$ phosphate $(7.5 \mathrm{M})$ and isopropanol $(0.7 \times \mathrm{vol})$, the DNA was precipitated and subsequently washed $2 \times$ with ethanol and finally resuspended in 50 to $100 \mu \mathrm{l}$ tris-ethylenediaminetetraacetic acid (TE) buffer, and stored at $-20^{\circ} \mathrm{C}$ until use.

DGGE analyses. Primer pairs specific for Eubacteria (341f and 907r; Muyzer et al. 1993) were used to amplify the $566 \mathrm{bp}$ long $16 \mathrm{~S}$ rRNA gene fragments. At the 5 '-end of each forward primer, an additional 40 bp GC-rich nucleotide sequence (GC-clamp) was added to stabilize migration of the DNA fragments in the DGGE gel (Muyzer et al. 1993). The reaction mixtures for the PCR amplification contained 2 to 
$5 \mu \mathrm{l}$ template DNA, $200 \mathrm{nM}$ of each of the appropriate primers, $250 \mu \mathrm{M}$ of each deoxyribonucleoside triphosphate, $2 \mathrm{mM}$ of $\mathrm{MgCl}_{2}, 5 \mu \mathrm{l}$ of $10 \times \mathrm{PCR}$ buffer, and $0.5 \mathrm{U}$ of BIOTAQ Red DNA polymerase (Bioline) in a total reaction volume of $50 \mu \mathrm{l}$. PCR reactions were performed in a Gradient Cycler PT-200 (MJ Research) using an initial denaturation step at $95^{\circ} \mathrm{C}$ (3 min), followed by 30 cycles of denaturation at $95^{\circ} \mathrm{C}(1 \mathrm{~min})$, annealing at $55^{\circ} \mathrm{C}(1 \mathrm{~min})$, and extension at $72^{\circ} \mathrm{C}(2 \mathrm{~min})$. A final extension at $72^{\circ} \mathrm{C}$ (10 min) and subsequent cooling at $4^{\circ} \mathrm{C}$ completed the reaction. The amplified DNA was purified using the Nucleo Spin Extract II PCR purification kit (Macherey-Nagel) and stored at $-20^{\circ} \mathrm{C}$. DGGE was performed in a $7 \%(\mathrm{v} / \mathrm{v})$ polyacrylamide gel with a denaturing gradient that was modified from 40 to $70 \%$ (Eubacteria) of urea and formamide (Allgaier et al. 2007). Prior to loading of PCR products onto DGGE gels, DNA was quantified on agarose gels using a quantitative DNA ladder (low DNA mass ladder, Invitrogen). After electrophoresis at $100 \mathrm{~V}$ for $18 \mathrm{~h}$, DNA bands were stained with $1 \times$ SYBR gold (Molecular Probes) and documented using an AlphaImager 2200 transilluminator (Biozym).

Representatives of all bright and well-defined DGGE bands were excised and eluted in sterile water at $4^{\circ} \mathrm{C}$ overnight. The eluted DNA was re-amplified with primer $341 \mathrm{f}$ without the GC-clamp. The PCR products were purified using the NucleoSpin extract kit (Macherey-Nagel), quantified on agarose gels using a quantitative DNA ladder (high DNA mass ladder, Invitrogen), and sequenced using primer $341 \mathrm{f}$ together with BigDye Xterminator purification kit (Applied Biosystems). Some bands with identical running behavior were sequenced to determine sequence identity. Sequences obtained with ABI Prism 3100-Avant genetic analyzer (Applied Biosystems) were checked and corrected manually with the program Chromas (version 1.45, Technelysium).

Analyses of DGGE profiles. DGGE banding patterns were analyzed using the software package GelCompar II, version 3.5 (Applied Maths). Within GelCompar II, a band-based binary presence/absence table was calculated according to a similarity index using Dice correlation. The distance among clusters was calculated using UPGMA. A Mantel test using Monte Carlo randomization with 999 randomized runs (PCord, version 5.01) was conducted to compare the similarity matrices acquired.

Phylogenetic analysis. Phylogenetic analyses of the partial 16S rRNA gene sequences were done using the ARB software package (http://arb-home.de). The retrieved sequences were imported into an ARB database of 52000 reference sequences, including the closest related sequences determined by BLAST
(www.ncbi.nlm.nih.gov/BLAST/). Sequences were first aligned automatically by the integrated alignment module within the ARB package, and subsequently corrected manually.

For stability of the phylogenetic tree, a backbone tree was calculated with sequences $\geq 1400$ nucleotides. Consistency of branching patterns was checked by applying 2 phylogenetic reconstruction methods to the appropriate set of sequences, namely neighborjoining and maximum parsimony. Subsequently, sequences $\leq 1400$ nucleotides were added to the tree according to maximum parsimony criteria. To exclude highly variable positions within the 16S rRNA gene sequences, a $50 \%$ base frequency filter for Eubacteria was calculated. This filter uses only those sequence positions of the alignment where $50 \%$ of the analyzed sequences have identical entries. Thus, the phylogenetic calculations became more robust and potential alignment errors were excluded.

The partial sequences of the 16S rRNA gene fragments obtained in this study were deposited in GenBank with the accession numbers EU432278 to EU432330.

\section{RESULTS}

\section{Abundance and dynamics of bacteria}

At the beginning of the incubations, total bacterial numbers were $3.4 \times 10^{5}$ cells ml ${ }^{-1}$ for the $0-10 \mathrm{~m}$ sample, and $1.03 \times 10^{6}$ cells ml $^{-1}$ for the $40 \mathrm{~m}$ sample. Subsequently, bacterial numbers peaked in epilimnic batch cultures $(0-10 \mathrm{~m})$ at 4 and $8 \mathrm{wk}\left(6.4 \times 10^{5}\right.$ and $6.5 \times 10^{5}$ cells $\mathrm{ml}^{-1}$, respectively), but dropped to a low at $6 \mathrm{wk}\left(0.37 \times 105 \mathrm{cells}^{-1}\right)$ in the $40 \mathrm{~m}$ samples (Fig. 2). For dilution cultures, bacterial numbers peaked at 6 wk for both $0-10$ and $40 \mathrm{~m}$ samples $\left(1.40 \times 10^{6}\right.$ and $1.57 \times 10^{6}$ cells $\mathrm{ml}^{-1}$, respectively; Fig. 2). An increase at $8 \mathrm{wk}$ was also found for Eubacteria determined by CARD-FISH analyses, which accounted for up to 80.14 and $93.17 \%$ of total bacteria in the $0-10$ and $40 \mathrm{~m}$ dilution cultures, respectively.

There were no consistent differences in the abundance of Actinobacteria, Alphaproteobacteria, and Betaproteobacteria between bacterial source communities during the 8 wk incubation (data not shown). Respective percentage contributions $( \pm \mathrm{SD})$ of the 3 major bacterial groups to total bacteria in the $0-10$ and $40 \mathrm{~m}$ samples (lowest to highest over the entire incubation) were: Actinobacteria 0 to $5.2 \pm 1 \%$ and 0 to $7.9 \pm$ $1 \%$; Alphaproteobacteria 0 to $15.4 \pm 0.8 \%$ and 0 to 30.4 $\pm 3 \%$; Betaproteobacteria $5.1 \pm 1$ to $27.5 \pm 4 \%$ and 13.5 \pm 2 to $65.8 \pm 8 \%$, respectively. 


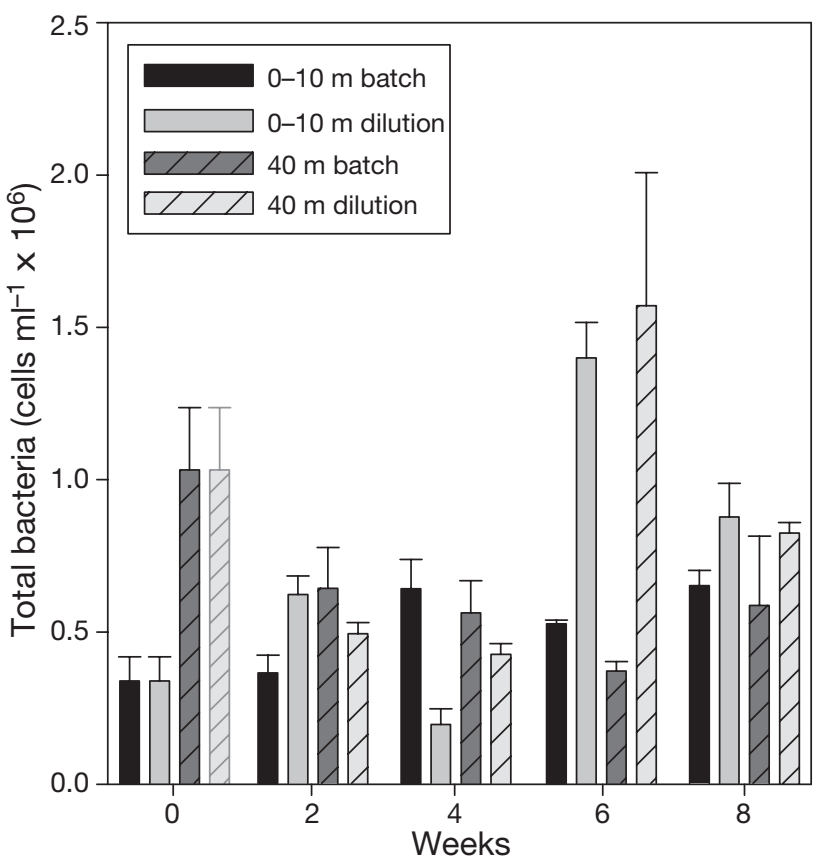

Fig. 2. Changes in total bacterial numbers $(+\mathrm{SD})$ in batch and dilution cultures of water from 2 different bacterial source communities following addition of humic matter (DAPI counts)

\section{Comparison of $\mathrm{BCC}$ at $0-10$ vs. $40 \mathrm{~m}$}

To compare BCC after HM addition, we distinguished the BCC of PA and FL fractions of initial lake water samples $\left(T_{0}\right)$ and compared them with those of samples from batch and dilution cultures using DGGE and cluster analysis (Dice index of DGGE banding patterns). In batch cultures from both the 0-10 and $40 \mathrm{~m}$ samples at $T_{0}$, the BCC of FL fractions formed a distinct cluster (Fig. 3a), in contrast to those of the PA fractions. After HM addition, the BCC from both 0-10 and $40 \mathrm{~m}$ samples formed distinct clusters including all 4 time points, i.e. weeks 2 to 8 . In dilution cultures from both the $0-10$ and $40 \mathrm{~m}$ samples at time $T_{0}$, the BCC of the FL and PA fractions formed separate clusters (Fig. 3b). After addition of HM, the BCC from the 0-10 m sample showed 2 subclusters depending on incubation time, while the BCC from the $40 \mathrm{~m}$ sample showed a single subcluster that varied with time and the BCC tended to be more similar to each other towards the end of the incubation.

\section{Comparison of $\mathrm{BCC}$ in batch vs. dilution cultures}

A cursory look at the DGGE banding patterns of BCC obtained after 8 wk of incubation from either 0-10 or $40 \mathrm{~m}$ samples showed different banding patterns in the batch and dilution cultures (Fig. 4). How-

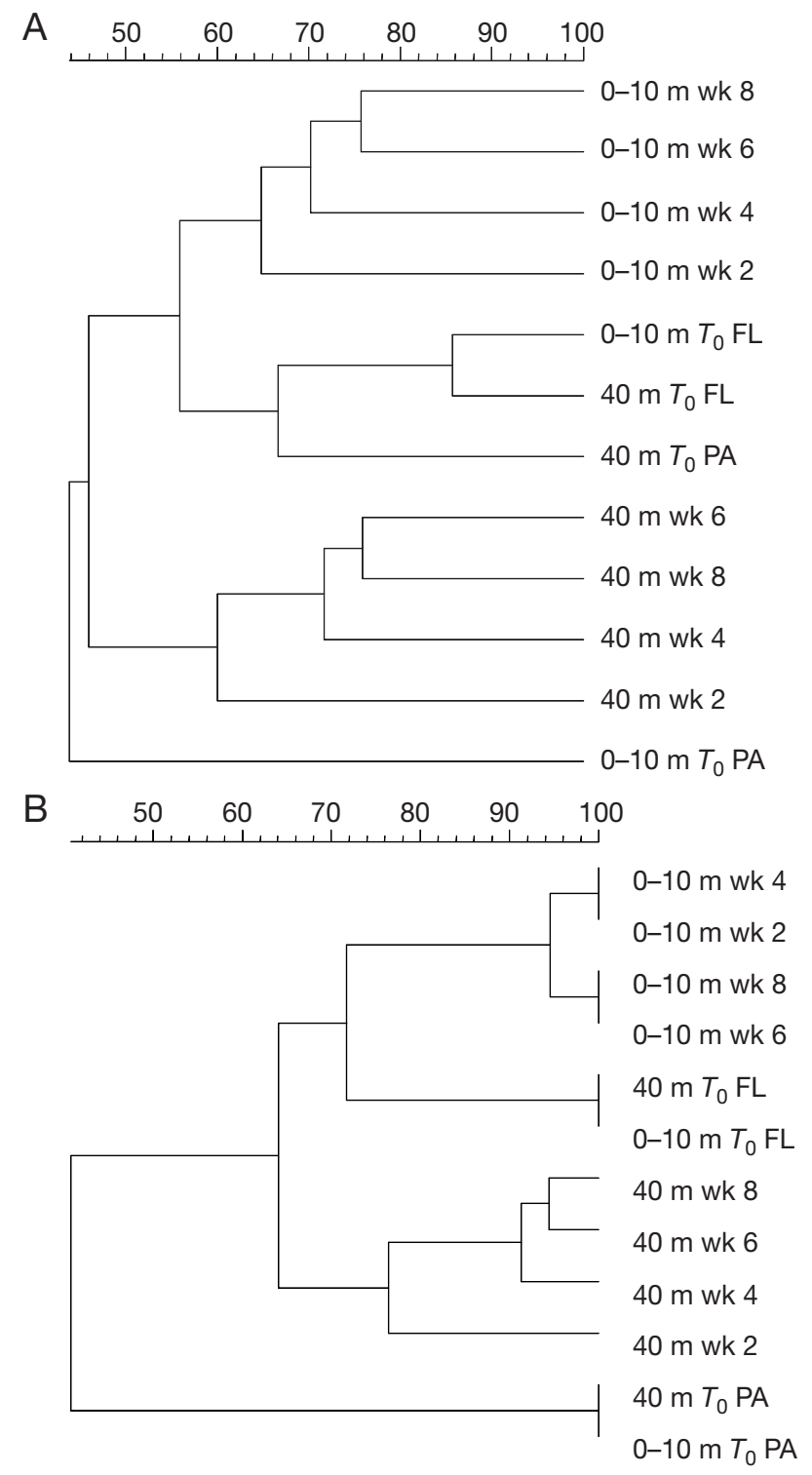

Dice (Tol 1.0-1.0\%) [0.0-100.0\%]

Fig. 3. Cluster analysis of eubacterial DGGE banding patterns of (A) batch culture and (B) dilution culture. $T_{0}$ : start of the experiment; FL: free-living bacteria; PA: particle-associated bacteria

ever, a Mantel test comparing the similarity matrices from batch and dilution cultures (Dice correlation; Fig. 3) showed a positive correlation ( $\mathrm{r}=0.556, \mathrm{p}=$ 0.001). Thus, both batch and dilution cultures lead to similar changes in the BCC following HM addition. The single marked difference between batch and dilution approaches was in the relative position of PA in the 0-10 m sample compared to that in the $40 \mathrm{~m}$ sample at $T_{0}$ (Fig. 3). This was attributable to a difference in total band intensity in the $40 \mathrm{~m}$ PA sample in the batch culture (Fig. 4). 


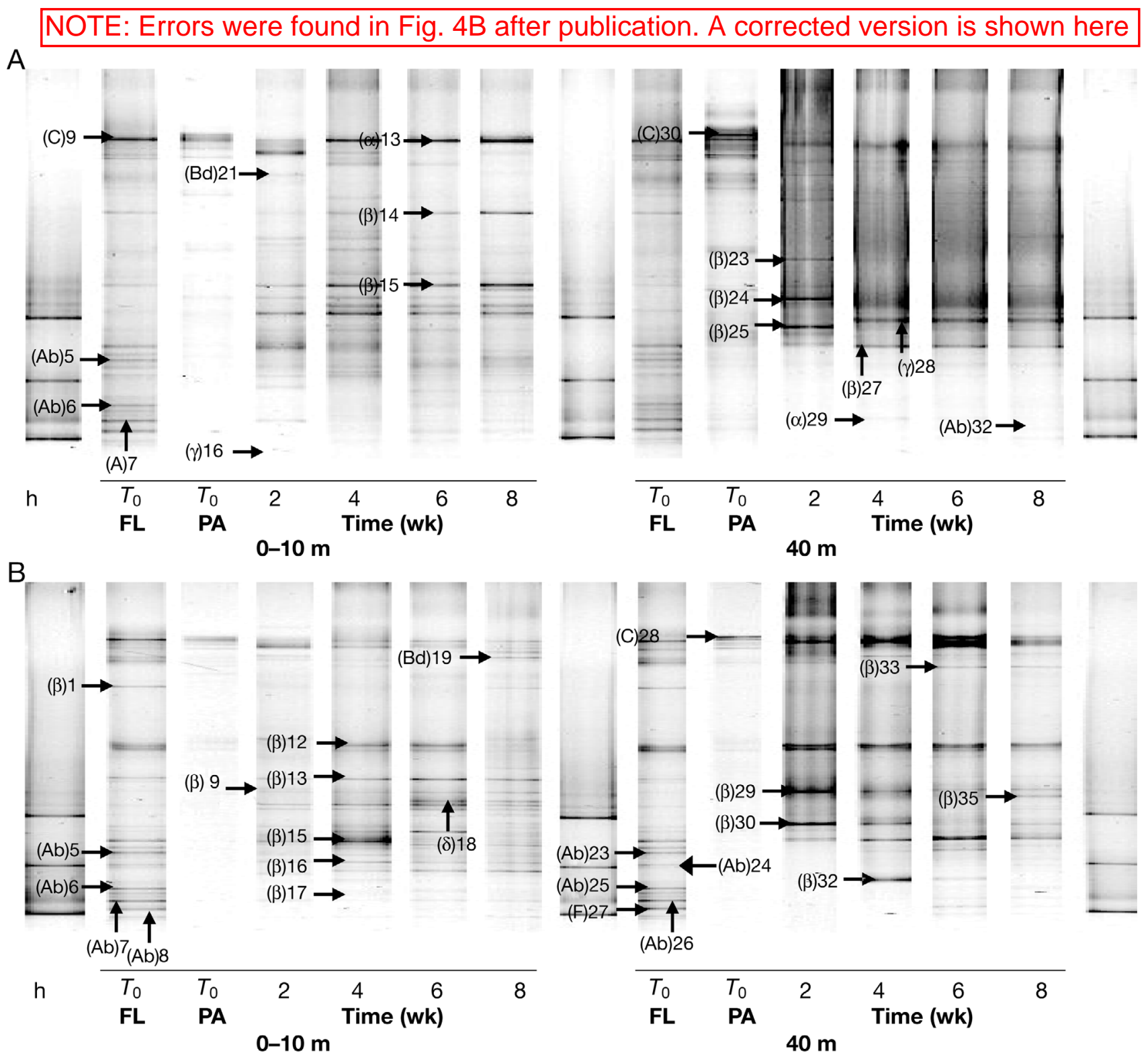

Fig. 4. DGGE gels of bacterial communities (using primers targeting 16S rRNA genes of Eubacteria) upon addition of humic matter: (A) batch culture, (B) dilution culture. FL: free-living bacteria, PA: particle-associated bacteria in initial samples at time zero $\left(T_{0}\right), \alpha$ : Alphaproteobacteria, $\beta$ : Betaproteobacteria, $\gamma$ : Gammaproteobacteria, Bd: Bacteroidetes, Ab: Actinobacteria, C: Cyanobacteria, F: Firmicutes, $\delta$ : Deltaproteobacteria. The standard is displayed to the right of each set. Sequenced bands are marked by arrows and the respective band numbers are given in Table A1

\section{Phylogeny of DGGE bands}

The DGGE fingerprint patterns of batch and dilution cultures are shown in Fig. 4 and the phylogenetic affiliation of the sequences are given in Table A1. The dominant bands in the initial lake water sample at $T_{0}$ represented bacteria belonging to typical freshwater groups (Zwart et al. 2002, Allgaier \& Grossart 2006b). FL Betaproteobacteria were closely related to uncultured clones L2Sp-25 (Methylophilus group) and MWH-IPGL7W22 (Polynucleobacter sp.). FL Actinobacteria were closely related to uncultured clones
L50W-39 and L50Sp-28, DGGE bands DRC-PA-DG1 and 30g1, and clones L50Sp-17 and L-2-64. PA bacteria were mainly related to a photoautotrophic cyanobacterium, which has a $99 \%$ similarity to a diatom chloropast (Table A1)/chloroplast.

A high variability in the DGGE banding patterns of Eubacteria was observed. In addition, the following trends were seen after 8 wk of incubation: (1) a few bacterial phylotypes, which formed major bands in the $T_{0}$ sample, continued to be present after HM addition; (2) bacteria related to Actinobacteria, which formed major bands in the $T_{0}$ sample, declined after HM addi- 
tion; and (3) bacterial phylotypes, that were not detected in the $T_{0}$ sample exhibited DGGE bands after $\mathrm{HM}$ addition. Each of these trends is presented in detail.

(1) Betaproteobacteria were common in the $T_{0}$ samples and persisted after HM additions (Fig. 4). The maximum percentages indicate the preferential growth of specific Betaproteobacteria populations in the presence of HM. Their most prominent representative belongs to the Polynucleobacter necessarius cluster (Burkert et al. 2003, Grossart et al. 2008) and is almost identical to isolate MHW-IPGL7W22 (Fig. 4a \& Table A1; Wu \& Hahn 2006). Its consistent presence in the $0-10 \mathrm{~m}$ sample during the entire incubation indicates that this bacterium is favored by HM additions.

Another Betaproteobacterium, closely related to clone CbS1s.06 (Propionivibrio group), was detected in the HM 0-10 m batch sample and was likely to be present in the $T_{0}$ sample (as inferred from the similar banding pattern). This bacterium became increasingly prominent during the $8 \mathrm{wk}$ incubation, indicating that it is able to tolerate and actively grow in the presence of HM.

(2) Several FL Actinobacteria were present in the $T_{0}$ samples from the lake, but were no longer detected upon HM addition. These bacteria were affiliated to uncultured clones L50W-39 and L50Sp-28 in the 0-10 m samples; and to DGGE bands DRC-PA-DG1 and 30g1, and clones L50Sp-17 and L-2-64 in the $40 \mathrm{~m}$ samples. The Betaproteobacterium closely related to clone L2Sp-25 (Methylophilus group) also disappeared after HM addition.

(3) Some bacteria were not detected in the DGGE banding pattern of the $T_{0}$ sample but were detected after HM addition. In the 0-10 m batch sample, a single phylotype, which is an Alphaproteobacterium closely related to an uncultured bacterium of the Roseisalinus group (DGGE band ESBAC-6), was detected only after HM addition. In contrast, in the 0-10 $\mathrm{m}$ dilution sample, multiple bacteria were detected only after HM addition; e.g. several Betaproteobacteria related to bacterium S09 (Herbaspirillum group), clone CbS1s.22 (Acidovorax group), clone YE28 (Acidovorax group), clone A50Su-14 (Comamonas group), and clone 268ds10 (Aquabacterium group); a Deltaproteobacterium related to bacterium K18 (Anaeromyxobacter group); and a Bacteroidetes related to clone IRD10C04 (Brumimicrobium group).

Similarly in the $40 \mathrm{~m}$ sample, HM addition in batch cultures revealed Betaproteobacteria related to clone TBa-14 (Janthinobacterium group), clone Toolik_Jun 2005_Tussock_170 (Duganella group), clone YE-28 (Acidovorax group), and clone L1A.9A11 (Rhodoferax group). HM addition in dilution cultures showed Betaproteobacteria related to clone 5RHF33 (Duganella group), clone A3m (Acidovorax group), clone C2.2rn (Leptothrix group), clone CbR3s.06 (Methylophilus group), and bacterium LH10 (Acidovorax group).

Some bacteria occurred only sporadically after HM additions but did not show a consistent pattern, such as Gammaproteobacteria related to clone Kas174B (Gemmatimonas group) and to clone FTL201 (Pseudomonas group), which were detected at 2 and 4 wk after HM addition in the $0-10$ and $40 \mathrm{~m}$ batch cultures, respectively.

The phylogenetic analysis of all 41 sequences representing the major DGGE bands acquired from both batch and dilution cultures revealed that 18 sequences (44\%) belonged to Betaproteobacteria, 12 (29\%) to Actinobacteria, $3(7 \%)$ to Cyanobacteria, 2 (5\%) to Bacteroidetes, $2(5 \%)$ to Alphaproteobacteria, $2(5 \%)$ to Gammaproteobacteria, 1 (2\%) to Deltaproteobacteria, and $1(2 \%)$ to Firmicutes. Although most of the sequences fell into well-established groups, 10 (24\%) had no nearest isolate relative and $8(20 \%)$ had a similarity of $97 \%$ or less to their nearest isolate relative (Table A1).

\section{Cultivation of bacterial isolates}

A total of 11 bacterial isolates was obtained (Table A2), all of which were subsequently screened by PCR with eubacterial primers and used for further analysis. The cultures were identified as members of 3 different phylogenetic groups (Table A2): 4 Alphaproteobacteria (36\%), 4 Betaproteobacteria (36\%), and 3 Gammaproteobacteria (27\%). Several isolates could be easily grown on plates after HM addition using our cultivation approach.

Although the isolates were grown on solid media with the same constituents as used in both batch and dilution cultures, the isolates were different from the major bands in our DGGE gels, but were related to them: Alphaproteobacteria were related to bacterium N7 (Methylobacterium, ISO 115), clone 28RHF13 (Devosia, ISO 117), bacterium MB12 (Rhodopila, ISO $117 \mathrm{~b}$ ), and clone P385 (Gluconacetobacter, ISO 118); Betaproteobacteria were related to CHNCT9 (Variovorax, ISO 103b+109), bacterium oxSCC-30 (Rhodoferax, ISO 121), and bacterium S-99 (Herbaspirillum, ISO 123); and Gammaproteobacteria were related to clone S011D (Lysobacter, ISO 110), strain SPS-9, and clone VAS26 (Pseudomonas, ISO 113 and ISO 116b).

\section{Inferences on freshwater bacterial phylogeny}

The phylogenetic relationships of all sequenced DGGE bands and isolates are given in Fig. 5. Most of the DGGE bands and isolates belonged to various 


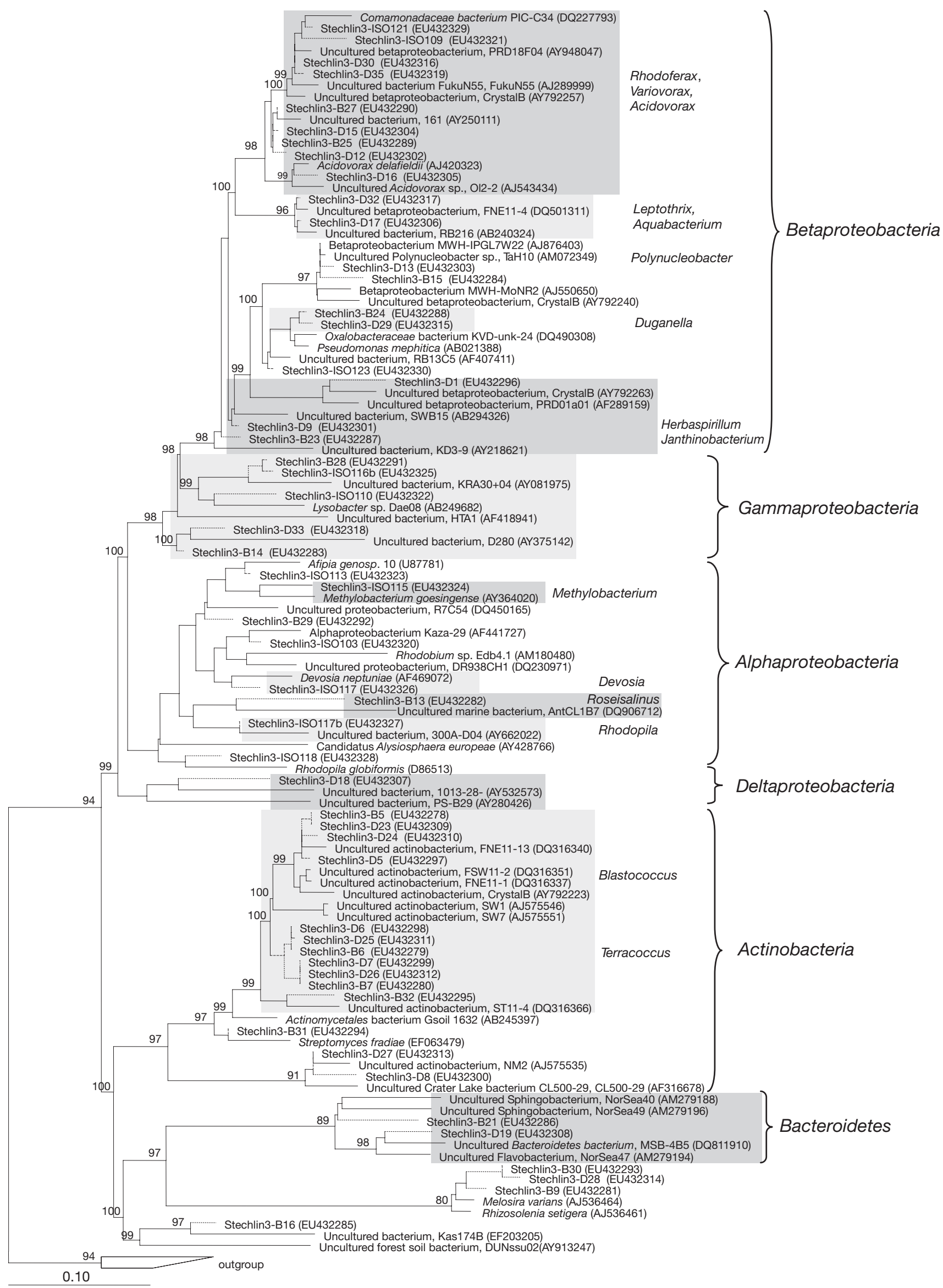


Fig. 5. Phylogenetic tree of 16S rRNA gene sequences of all DGGE bands and isolates from initial natural water samples of Lake Stechlin and from the batch and dilution cultures with added humic matter. Solid lines indicate sequences that were analyzed using maximum likelihood criteria (sequences of $>1400$ nucleotides), and broken lines indicate sequences that were added to the tree using maximum parsimony criteria (sequences of $<1400$ nucleotides). Sequences isolated in the present study are highlighted in grey, and GenBank accession numbers are given in parentheses. B and D: batch and dilution cultures, respectively. Bootstrap values at the main branching points are given. Phylogenetic groupings are highlighted with gray boxes

clusters of Alphaproteobacteria, Bacteroidetes, Betaproteobacteria, Deltaproteobacteria, or Gammaproteobacteria, which do not belong to specific freshwater clusters. Actinobacteria, however, were mainly members of the freshwater cluster acI-B. Inferences were based on groupings made by Glöckner et al. (2000), Urbach et al. (2001), Zwart et al. (2002), Warnecke et al. (2004), Gich et al. (2005), Allgaier \& Grossart (2006a), and Newton et al. (2006).

\section{DISCUSSION}

We observed pronounced differences in the development of BCC following HM addition to epilimnic vs. hypolimnic samples kept at their respective in situ temperatures. This suggests that the bacterial source community, in combination with temperature, is important for the establishment of specific bacterial communities following HM input. These results are partially supported by the findings of Langenheder et al. (2005), who demonstrated that medium and inoculum both separately influence BCC in batch cultures. These changes in $\mathrm{BCC}$ reflect the presence of 2 types of bacteria: (1) specific bacteria that grow only under selected conditions, and (2) metabolically versatile taxa that quickly adapt to new substrates.

Moreover, our study shows that BCC changes in a similar manner whether kept in batch or dilution cultures. This indicates that single and repeated HM pulses select for a similar bacterial community structure. Thus, BCC is not regulated by selection due to single or repeated HM addition. Instead, the history and taxa of the source community seem to be stronger regulating factors in shaping the BCC (see also Kirchman et al. 2004, Langenheder et al. 2006).

\section{Presence of specific bacteria following HM addition}

$\mathrm{HM}$ addition to the native BCC of oligotrophic Lake Stechlin selected for a highly specific bacterial commu- nity. Addition of HM favored the growth of Betaproteobacteria such as a member of the Polynucleobacter sub-clade identical to isolate MHW-IPGL7W22. Related Betaproteobacteria are well adapted to their natural organic matter field in humic Lake Grosse Fuchskuhle (Grossart et al. 2008). For example, several isolates of the Polynucleobacter sub-clade were found to grow on low molecular weight substances such as acetate and propionate, which are known to be byproducts of photolysis and anaerobic humic matter degradation (Hahn et al. in press). Since we cannot rule out a possible change in the chemical features of our HM concentrate during the isolation procedure, there is a slight chance that HM or its byproducts, such as acetate, may explain the exceptional persistence of this bacterium. Several other Betaproteobacteria, including Acidovorax, Herbaspirillum, and Methylophilus species, were also favored by HM addition and are present in a variety of humic lakes (Burkert et al. 2003, Pearce et al. 2005, Newton et al. 2006, Grossart et al. 2008). They represent a major fraction of limnetic bacterioplankton (Méthe et al. 1998, Crump et al. 1999, Zwart et al. 2002) and their abundance is significantly increased by supplementation with HM-rich soil DOM, which correlated well with the total metabolic activity of the bacterioplankton (Perez \& Sommaruga 2006).

In contrast, freshwater Actinobacteria of the ac clade, which is one of the most abundant groups of freshwater bacteria in temperate lakes, decreased in abundance after HM addition, suggesting that most of them are not able to utilize HM or its byproducts. These Actinobacteria are an autochthonous component of many lakes, including Lake Stechlin (Warnecke et al. 2005, Allgaier \& Grossart 2006a, Newton et al. 2006). We were unable to obtain Actinobacteria of the ac clade in pure culture; hence, their metabolic capacities still need to be investigated. Their low abundance in our HM cultures, however, may suggest that growth of most Actinobacteria of the ac clade in lakes is supported by environmental factors other than inorganic nutrients and HM (Allgaier \& Grossart 2006a).

Several other bacteria that were detected at different incubation times, but which did not show consistent patterns of growth after HM addition, were Actinobacteria (Frigoribacterium), Alphaproteobacteria (Methylocystis and Roseisalinus), Bacteroidetes (Brumimicrobium and Crocinitomix), Betaproteobacteria (Aquabacterium, Comamonas, Duganella, Janthinobacterium, Leptothrix, Propionivibrio, and Rhodoferax), and Gammaproteobacteria (Gemmatimonas). Most of these bacteria have been previously found in plankton, lake sediment, groundwater and drinking water (Höfle et al. 1999, Meijer et al. 1999, Jung et al. 2004, Bowman et al. 2005, Labrenz et al. 2005, Loy et 
al. 2005, Xiao et al. 2005, Lindner et al. 2007). Their growth may have benefited from changes in $\mathrm{pH}$ and the presence of other bacteria and/or their metabolic products in the cultures. It is als possible that their growth is favoured in mixed culture, and thus might be independent of HM itself. These bacteria are presumably able to rapidly adapt to conditions following HM addition or are generalists capable of utilizing a wide range of organic matter including $\mathrm{HM}$ and its degradation products.

\section{Cultivation of bacteria after HM addition}

HM addition either in batch or dilution cultures can be successfully used for isolation of rare bacteria, such as those related to Devosia, Lysobacter, Pseudomonas, Rhodopila, and Variovorax species. Our simple isolation approach does not account for important environmental conditions, such as hydrodynamics, protozoan predation, and viral lysis. However, it has the advantage of isolating some potentially important HMdegrading bacteria. Isolates on HM-rich media, such as our Pseudomonas isolates, are known to degrade a variety of polymeric and aromatic compounds (Brenner et al. 2005). Variovorax species have been previously found after nutrient enrichment of samples from an Antarctic freshwater lake (Pearce et al. 2005). It has been suggested that Methylobacterium species can actively utilize HM (Moosvis et al. 2005). Thus, addition of HM via allochthonous supply into Lake Stechlin may select for specific phylotypes that are not necessarily major bacterial phylotypes in the lake, but which are important HM-degrading bacteria. This shows that potentially important HM-degrading bacteria are present in microbial populations even in oligotrophic Lake Stechlin. Their isolation, in addition to controlled community manipulation experiments, could provide more subtle phylogenetic differences and determine ecologically relevant features of these bacteria in the future.

Acknowledgements. We thank E. Mach for technical assistance during sampling and for measurement of dissolved organic carbon. This work was supported by a PhD scholarship to K.M.L.H.S. from the Deutscher Akademischer Austauschdienst (DAAD), by the Leibniz Foundation, and by a course travel grant to K.M.L.H.S. from Boehringer Ingelheim Fonds.

\section{LITERATURE CITED}

Allgaier M, Grossart HP (2006a) Diversity and seasonal dynamics of Actinobacteria populations in four lakes in northeastern Germany. Appl Environ Microbiol 72: 3489-3497

Allgaier M, Grossart HP (2006b) Seasonal dynamics and phy- logenetic diversity of free-living and particle-associated bacterial communities in four lakes of northeastern Germany. Aquat Microb Ecol 45:115-128

Allgaier M, Brückner S, Jasper E, Grossart HP (2007) Intraand inter-lake variability of free-living and particle-associated Actinobacteria communities. Environ Microbiol 9: $2728-2741$

Bowman JP, Nichols CM, Gibson JAE (2003) Algoriphagus ratkowskyi gen. nov., sp. nov., Brumimicrobium glaciale gen. nov., sp. nov., Cryomorpha ignava gen. nov., sp. nov., and Crocinitomix catalasitica gen. nov., sp. nov., novel flavobacteria isolated from various polar habitats. Int $\mathrm{J}$ Syst Evol Microbiol 53:1343-1355

Brenner DJ, Krieg NR, Staley JT (2005) Bergey's manual of systematic bacteriology, Vol 2, Part B and C. Springer Science and Business Media, New York

Burkert U, Warnecke F, Babenzien D, Zwirnmann E, Pernthaler J (2003) Members of readily enriched $\beta$-proteobacterial clade are common in surface waters of a humic lake. Appl Environ Microbiol 69:6550-6559

Casper SJ (ed) (1985) Lake Stechlin: a temperate oligotrophic lake. Dr. W. Junk B. V. Publishers, Dordrecht

Castle D, Kirchman D (2004) Composition of estuarine bacterial communities assessed by denaturing gradient gel electrophoresis and fluorescence in situ hybridization. Limnol Oceanogr Methods 2:303-314

Crump BC, Armbrust EV, Baross JA (1999) Phylogenetic analysis of particle-attached and free-living bacterial communities in the Columbia River, its estuary, and the adjacent coastal ocean. Appl Environ Microbiol 65:3192-3204

Crump BC, Kling GW, Bahr M, Hobbie JE (2003) Bacterioplankton community shifts in an Arctic lake correlate with seasonal changes in organic matter source. Appl Environ Microbiol 69:2253-2268

Daims H, Bruhl A, Amann R, Schleifer KH, Wagner M (1999) The domain-specific probe EUB338 is insufficient for the detection of all bacteria: development and evaluation of a more comprehensive probe set. Syst Appl Microbiol 22:434-444

> Gich F, Schubert K, Bruns A, Hoffelner H, Overmann J (2005) Specific detection, isolation and characterization of selected, previously uncultured members of the freshwater bacterioplankton community. Appl Environ Microbiol 71:5908-5919

Glöckner FO, Fuchs BM, Amann R (1999) Bacterioplankton compositions of lakes and oceans: a first comparison based on fluorescence in situ hybridization. Appl Environ Microbiol 65:3721-3726

Glöckner FO, Zaichikov E, Belkova N, Denissova L, Pernthaler J, Pernthaler A, Amann R (2000) Comparative 16S rRNA analysis of lake bacterioplankton reveals globally distributed phylogenetic clusters including an abundant group of Actinobacteria. Appl Environ Microbiol 66: 5053-5065

> Grossart HP, Jezbera J, Hornak K, Hutalle KML, Buck U, Simek K (2008) Abundance and in situ activities of major bacterial groups in Lake Grosse Fuchskuhle (northeastern Germany). Environ Microbiol 10:635-652

Hahn MW (2003) Isolation of strains belonging to the cosmopolitan Polynucleobacter necessarius cluster from freshwater habitats located in three climatic zones. Appl Environ Microbiol 69:5248-5254

Hahn MW, Lünsdorf H, Wu Q, Schauer M, Höfe MG, Boenigk J, Stadler P (2003) Isolation of novel ultramicrobacteria classified as Actinobacteria from five freshwater habitats in Europe and Asia. Appl Environ Microbiol 69:1442-1451

> Hahn MW, Stadler P, Wu QL, Pöckl M (2004) The filtrationacclimatization method for isolation of an important frac- 
tion of the not readily cultivable bacteria. J Microbiol Methods 57:379-390

Hahn MW, Lang E, Brandt U, Wu QL, Scheuerl T (in press) Emended description of the genus Polynucleobacter and the species $P$. necessarius and proposal of the two subspecies $P$. necessarius subsp. necessarius subsp. nov. and $P$. necessarius subsp. asymbioticus subsp. nov. Int J Syst Evol Microbiol

Haukka K, Heikkinen E, Kairesalo T, Karjalamin H, Sivonen K (2005) Effect of humic material on the bacterioplankton community composition in boreal lakes and mesocosms. Environ Microbiol 7:620-630

Höfle MG, Haas H, Dominik K (1999) Seasonal dynamics of bacterioplankton community structure in a eutrophic lake as determined by 5S rRNA analysis. Appl Environ Microbiol 65:3164-3174

Jung DO, Achenbach LA, Karr EA, Takaichi S, Madigan MT (2004) A gas vesiculate planktonic strain of the purple non-sulfur bacterium Rhodoferax antarcticus isolated from Lake Fryxell, Dry Valleys, Antarctica. Arch Microbiol 182:236-243

Kirchman DL, Dittel AI, Findlay SEG, Fischer D (2004) Changes in bacterial activity and community structure in response to dissolved organic matter in the Hudson River, New York. Aquat Microb Ecol 35:243-257

Labrenz M, Lawson PA, Tindall BJ, Collins MD, Hirsch P (2005) Roseisalinus antarcticus gen. nov., sp. nov., a novel aerobic bacteriochlorophyll a-producing $\alpha$-proteobacterium isolated from hypersaline Ekho Lake, Antarctica. Int J Syst Evol Microbiol 55:41-47

Langenheder S, Lindström ES, Tranvik LJ (2005) Weak coupling between community composition and functioning of aquatic bacteria. Limnol Oceanogr 50:957-967

Langenheder S, Lindström ES, Tranvik LJ (2006) Structure and function of bacterial communities emerging from different sources under identical conditions. Appl Environ Microbiol 72:212-220

Lindner AS, Pacheco A, Aldrich HC, Staniec AC, Uz I, Hodson DJ (2007) Methylocystis hirsuta sp. nov., a novel methanotroph isolated from a groundwater aquifer. Int J Syst Evol Microbiol 57:1891-1900

Lindström ES (2000) Bacterioplankton community composition in five lakes differing in trophic status and humic content. Microb Ecol 40:104-113

Loy A, Beisker W, Meier H (2005) Diversity of bacteria growing in natural mineral water after bottling. Appl Environ Microbiol 71:3624-3632

Manz W, Amann R, Ludwig W, Wagner M, Schleifer KH (1992) Phylogenetic oligodeoxynucleotide probes for the major subclasses of proteobacteria: problems and solutions. Syst Appl Microbiol 15:593-600

Meijer WG, Nienhuis-Kuiper ME, Hansen TA (1999) Fermentative bacteria from estuarine mud: phylogenetic position of Acidaminobacter hydrogenoformans and description of a new type of gram-negative, propionigenic bacterium as Propionibacter pelophilus gen. nov., sp. nov. Int J Syst Bacteriol 49:1039-1044

Méthe BA, Hiorns WD, Zehr JP (1998) Contrasts between marine and freshwater bacterial community composition: analysis of communities in Lake George and six other
Adirondack lakes. Limnol Oceanogr 43:368-374

> Moosvi SA, McDonald IR, Pearce DA, Kelly DP, Wood AP (2005) Molecular detection and isolation from Antarctica of methylotrophic bacteria able to grow with methylated sulfur compounds. Syst Appl Microbiol 28:541-554

Muyzer G, de Waal E, Uitterlinden A (1993) Profiling of complex microbial populations by denaturing gradient gel electrophoresis analysis of polymerase chain reactionamplified genes coding for 16S rRNA. Appl Environ Microbiol 59:695-700

> Newton RJ, Kent AD, Triplett EW, McMahon KD (2006) Microbial community dynamics in a humic lake: differential persistence of common freshwater phylotypes. Environ Microbiol 8:956-970

Pearce DA, van der Gast CJ, Woodward K, Newsham KK (2005) Significant changes in the bacterioplankton community structure of a maritime Antarctic freshwater lake following nutrient enrichment. Microbiology 151: 3237-3248

Perez MT, Sommaruga R (2006) Differential effect of algaland soil-derived dissolved organic matter on alpine lake bacterial community composition and activity. Limnol Oceanogr 51:2527-2537

Pernthaler J, Amann R (2005) Fate of heterotrophic microbes in pelagic habitats: focus on populations. Microbiol Mol Biol Rev 69:440-461

Roller C, Wagner M, Amann R, Ludwig W, Schleifer K (1994) In situ probing of gram-positive bacteria with high DNA G + C content using 23S rRNA-targeted oligonucleotides. Microbiology 140:2849-2858

Sachse A, Babenzien D, Ginzel G, Albrecht J, Steinberg CEW (2001) Characterization of dissolved organic carbon (DOC) in a dystrophic lake and an adjacent fen. Biogeochemistry 54:279-296

Sekar R, Pernthaler A, Pernthaler J, Warnecke F, Posch T, Amann R (2003) An improved protocol for quantification of freshwater Actinobacteria by fluorescence in situ hybridization. Appl Environ Microbiol 69:2928-2935

Urbach EK, Vergin L, Young L, Morse A, Larson GL, Giovanni SJ (2001) Unusual bacterioplankton community structure in ultraoligotrophic Crater Lake. Limnol Oceanogr 46: $557-572$

Warnecke F, Amann R, Pernthaler J (2004) Actinobacterial 16S rRNA genes from freshwater bacteria affiliated with class Actinobacteria. Environ Microbiol 6:242-253

Warnecke F, Sommaruga R, Sekar R, Hofer J, Pernthaler J (2005) Abundances, identity and growth of Actinobacteria in mountain lakes of different UV transparency. Appl Environ Microbiol 71:5551-5559

Wu QL, Hahn MW (2006) Differences in structure and dynamics of Polynucleobacter communities in a temperate and a subtropical lake, revealed at three phylogenetic levels. FEMS Microbiol Ecol 57:67-79

$>$ Xiao X, Yin X, Lin J, Sun L, You Z, Wang P, Wang F (2005) Chitinase genes in lake sediments of Ardley Island, Antarctica. Appl Environ Microbiol 71:7904-7909

> Zwart G, Crump BC, Kamst-van Agterveld MP, Hagen F, Han SK (2002) Typical freshwater bacteria: an analysis of available 16S rRNA gene sequences from plankton of lakes and rivers. Aquat Microb Ecol 28:141-155 
Appendix 1. Preliminary test of humic matter addition on bacterial diversity and phylogenetic affiliation of sequenced DGGE bands and isolates

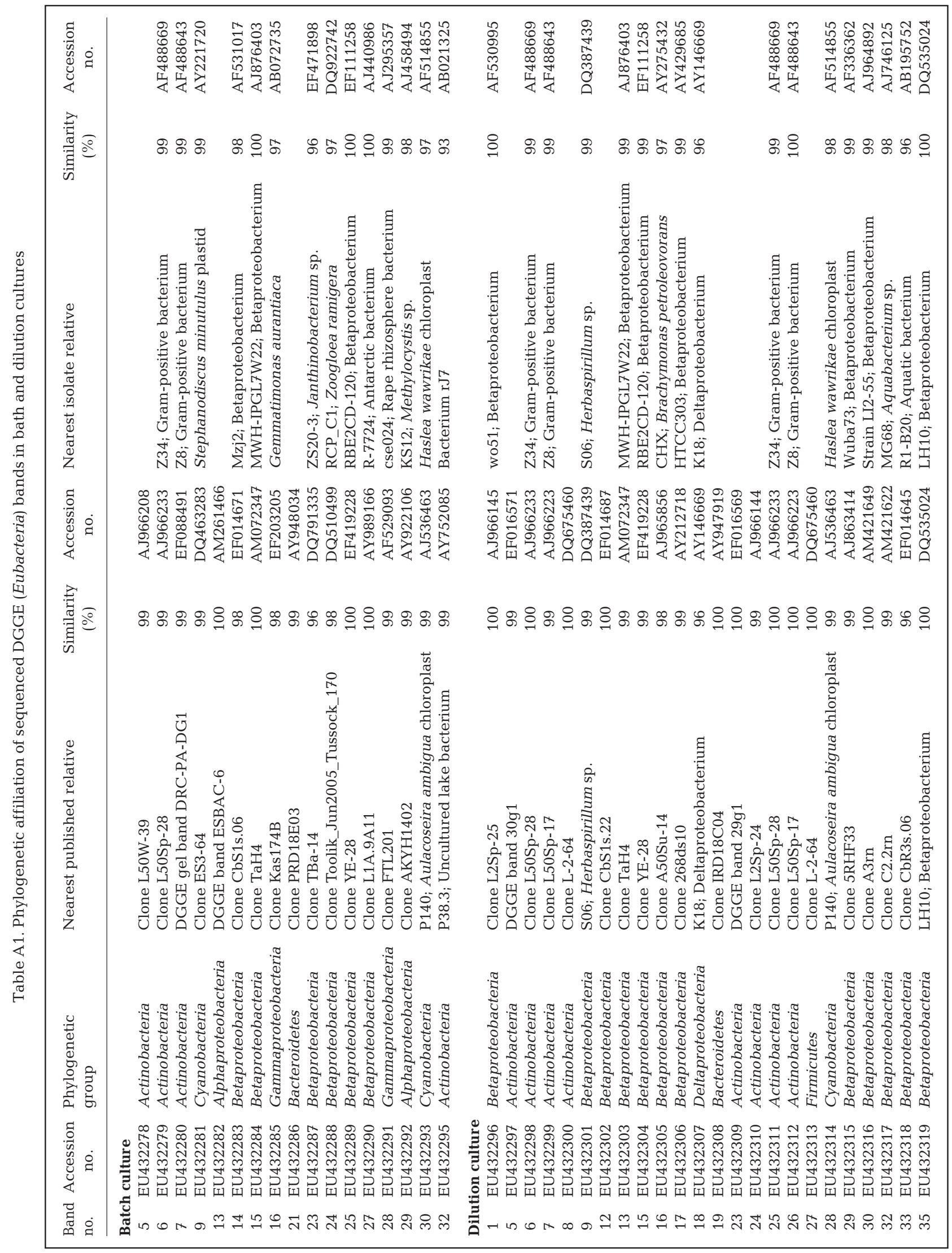




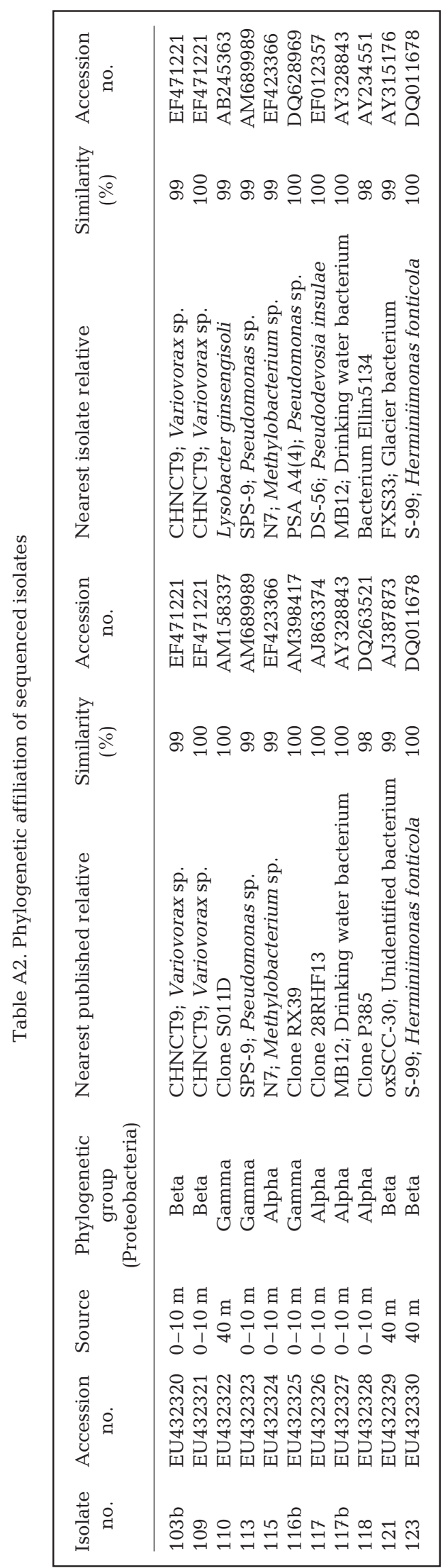

Editorial responsibility: Karel Šimek, Česke Budejoviče, Czech Republic
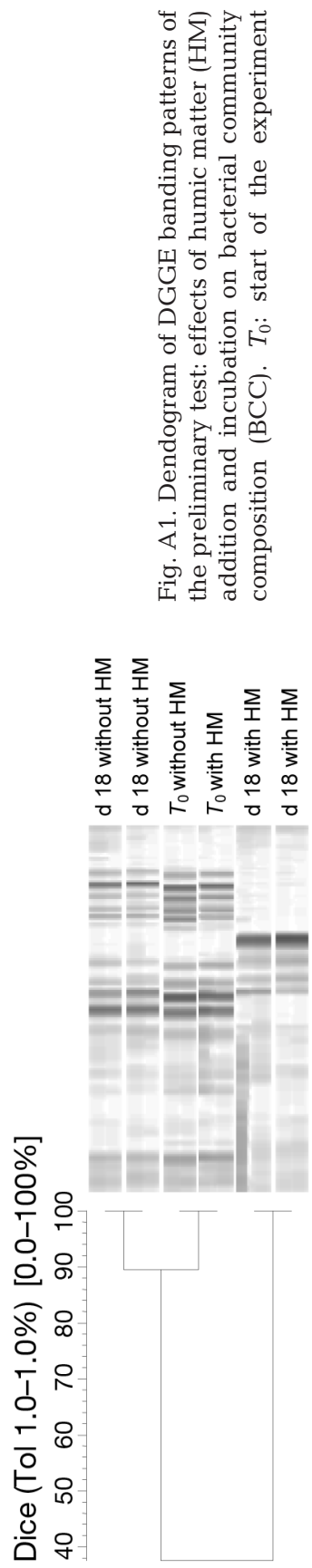

Submitted: July 29, 2008; Accepted: February 5, 2009 Proofs received from author(s): April 16, 2009 